\section{Conservation swap restores corridor in a biodiversity hotspot}

Kudremukh National Park in Karnataka State, India, forms the largest block of biodiversity-rich tropical rainforests in the Western Ghats, recognized as one of the 38 global Biodiversity Hotspots. However, the presence of an iron-ore mine established in 1977 has meant that a $25 \mathrm{~km}$ high-tension power line cut across the heart of the park, fragmenting and disrupting several threatened species, including the largest population of lion-tailed macaques in the wild. Forced to close down recently following litigation by conservation groups, the now defunct mine still remained linked by the massive power line. However, a significant conservation victory was recently achieved when this corridor was restored by a unique conservation swap mandated by the Forest Advisory Committee (FAC) of the Indian Government.

In early 2010 the government of Karnataka State sought FAC's mandatory approval for another high-tension power line to take power from a newly constructed thermal power plant. Because the proposed power line cut through $8.3 \mathrm{~km}$ of evergreen forest corridor south of Kudremukh National Park, FAC mandated field inspection by Wildlife Conservation Society scientist K. Ullas Karanth and Former Dean, Wildlife Institute of India, A.J.T. Johnsingh. Based on the analysis provided by Karanth and Johnsingh FAC permitted the new power line conditional on compensatory dismantling of the existing $25 \mathrm{~km}$ power transmission line in Kudremukh, thereby restoring the lost corridor within the Park. This dismantling of a major power line, from a conservation swap, is the first of its kind in India. It is expected to be a precedent-setting conservation model as India tries to reconcile the twin social goals of preserving nature and achieving economic growth, both essential for the welfare of its 1.2 billion people.

PRERNA Singh BINDRA Wildlife Conservation Society-India Program, Centre for Wildlife Studies, 1669, 31st Cross, 16th Main, Banashankari 2nd Stage, Bengalooru-560 070, India E-mail prerna.wcsindia@gmail.com

\section{PARKS journal relaunched}

The PARKS journal from the IUCN World Commission on Protected Areas is being relaunched at the World Conservation Congress in September 2012 as an online, open access, peer-reviewed journal, covering field and policy research that contributes directly to protected area management. It aims to strengthen international collaboration in protected area development and management by serving as a global forum for the exchange of information. The journal will cover all protected area management approaches and governance types. It will focus on research that helps ensure protected areas fulfil their primary role in nature conservation, while also addressing critical issues such as ecologically sustainable development, social justice and climate change adaptation and mitigation. Particular encouragement will be given to contributors with direct and in-depth field experience, including protected area managers and rangers as well as researchers and academics. We invite submissions from those involved in innovative approaches to protected area management and governance, including indigenous and community conserved areas, financial sustainability and development of professional standards. The principal readership will be protected area specialists, researchers, students, policy makers and protected area managers from around the world. Papers submitted for publication should be evidence-based, using accepted scientific methods or drawing upon precise observations to support conclusions. Purely theoretical studies without field application are unlikely to be accepted. Papers that stimulate debate on new or forthcoming issues relevant to protected areas, such as linkages to convention targets, will normally be commissioned. PARKS will be available at http://www.iucn.org/ about/union/commissions/wcpa/wcpa_puball/wcpa_parksmag/ wcpa_parkseditorialpolicy/

Sue Stolton and Nigel Dudley Equilibrium Research, 47 The Quays, Cumberland Road, Bristol, BS1 6UQ, UK E-mailnigel@equilibriumresearch.com

Kathy MacKinNon World Commission on Protected Areas 